\title{
KRAS Mutation is a Local Tumour Event and Not a Field Change in Pancreatobiliary Tumours
}

\author{
M. D. Chandrasegaram ${ }^{1 *}$, D. Y. Chen ${ }^{1}$, C. P. Tan ${ }^{1}$, E. L. Neo, \\ P. M. Dolan ${ }^{1}$, J. W. Chen ${ }^{1}$, M. E. Brooke-Smith ${ }^{1}$, G. Cheetham ${ }^{2}$, \\ A. Ruszkiewicz ${ }^{3}$ and C. S. Worthley ${ }^{1}$ \\ ${ }^{1}$ Hepatopancreatobiliary (HPB) Surgery Unit, Royal Adelaide Hospital, Adelaide, Australia. \\ ${ }^{2}$ Department of Molecular Pathology,SA Pathology (Royal Adelaide Hospital site), Adelaide, \\ Australia. \\ ${ }^{3}$ Department of Tissue Pathology, SA Pathology (Royal Adelaide Hospital site), Adelaide, \\ Australia.

\section{Authors' contributions} \\ This work was carried out in collaboration between all authors. Author CSW designed the \\ study, gained ethics approval and funding, performed the statistical analysis, wrote the \\ protocol and revised the manuscript. Author MDC coordinated the study, recruited patients, \\ wrote the first draft, revised the manuscript, managed the analyses and performed the \\ literature searches. Author DYC recruited patients and was involved in the analyses and was \\ involved in the drafting and revisions. Author AR performed the pathological study and \\ analyses and was involved in the drafting and revisions. Author GC conducted the genomic \\ analyses of the specimens and was involved in the drafting and revisions. Authors CPT, \\ ELN, JWC, PMD, and MEBS participated in the study design, reviewed and revised the \\ manucript and literature searches. All authors read and approved the final manuscript.
}

Research Article

Received 24 ${ }^{\text {th }}$ April 2013

Accepted 25 $5^{\text {th }}$ June 2013

Published $12^{\text {th }}$ July 2013

\section{ABSTRACT}

Background: KRAS mutation (KRM) is the earliest, most common mutation in pancreatic cancer. Accurate assessment of tumour KRM status in pancreatobiiary tumours is relevant in an era of targeted molecular therapies.

Aim: To assess KRM in tumour and non-tumourous margin tissue in patients undergoing a pancreatic resection.

Study Design: Original research, retrospective review of prospectively collected specimens. 
Place and Duration of Study: Patients who had undergone pancreaticoduodenectomy and distal pancreatic resection at the Royal Adelaide Hospital from 2011-2012 were consented for the study.

Methods: Patient demographics, background history and tumour details were collated. Tumour tissue and margin areas were macrodissected from FFPE tissue sections following identification by a pathologist. DNA was prepared from the tissue using the QIAamp FFPE Tissue kit (Qiagen $\mathrm{GmbH}$, Hilden Germany). KRM at codons 12 and 13 was assessed using SNaPShot ${ }^{\mathrm{TM}}$ (Applied Biosystems, Warrington UK) in tumour tissue and non-tumourous margin tissue.

Fourteen patients were included in the study. The median age of the patients in the study was 68 (range 57-86) years. The $M: F$ ratio was $8: 6$.

Results: Twelve patients had adenocarcinomas (5 pancreatic; 4 ampullary, 3 biliary) and two had benign mucinous tumours. Six patients with adenocarcinomas had KRM (5@codon 12 and 1@codon 13). Margin tissue was negative for KRM in all the tested patients ( $p<0.016$ Fisher) particularly, in those with tumour KRM.

Tumours with KRM were associated with larger tumours 30(22-65) $\mathrm{mm}$ vs 20(15-35) mm [median(range)] $(p=.045-\mathrm{MW}-\mathrm{U})$. Nodal disease occurred in $6 / 6$ with $\mathrm{KRM}$ vs $2 / 6$ without KRM ( $p=.61-$ Fisher).

Conclusions: KRM is a local tumour event and not a field change. This suggests that testing for KRM should be reliant on tumour tissue and not surrounding normal margin tissue. KRM was associated with larger malignant tumours and a trend towards nodal disease.

Keywords: Biliary cancer; KRAS mutation; margin status; pancreatic cancer; ampullary cancer; prognosis.

\section{PRESENTED AT}

1) The Australian Health and Medical Research Congress (AHMRC) 2012, Adelaide, Australia.

2) The Australian and New Zealand Hepatobiliary (ANZHPBA) Meeting 2012, Queensland, Australia.

\section{INTRODUCTION}

The KRAS oncogene encodes a protein responsible for signaling in the mitogen activated (MAP)-kinase pathway of intracellular signal transcription. KRAS mutation results in continual activation of the protein with consequent continual stimulus for cellular proliferation. $K R A S$ mutation (KRM) is the earliest and most common mutation in pancreatic cancer [1,2]. KRAS point mutations at codon 12 are present in approximately $85-95 \%$ of pancreatic cancers $[3,4,5]$. The mutations are generally a single amino acid substitution in codon 12 or less frequently codon 13 . A single amino acid substitution from glycine $(G)$ to aspartic acid (D) at codon 12 is seen in up to $95 \%(60-95 \%)$ of pancreatic ductal cancers $[6,7]$.

The aim of this study was to assess KRM in resected pancreatobiliary tumours and the nontumourous margin tissue such that molecular changes within the tumour and surrounding tissue could be mapped. This was to assess if genomic alterations reflected a field change within the entire pancreas or if these changes occurred only in tumour tissue. 


\section{METHODOLOGY}

The study was approved by the Royal Adelaide Hospital Human Research Ethics Committee. We recruited patients from the Royal Adelaide Hospital Hepatopancreatobiliary Surgery Unit, using our web-based database. Patients who had undergone pancreaticoduodenectomy and distal pancreatic resection at our institution from 2011-2012 were identified. Patient demographics, background history and tumour details were collated. Tumour tissue and non-tumourous margin tissue was selected by a single pathologist.

Tumour tissue and margin areas were macrodissected from FFPE tissue sections following identification by a pathologist. DNA was prepared from the tissue using the QIAamp FFPE Tissue kit (Qiagen $\mathrm{GmbH}$, Hilden Germany). Plasma DNA was isolated from 3mL K2EDTA plasma using the QIAamp Circulating Nucleic Acid kit (Qiagen $\mathrm{GmbH}$, Hilden Germany). KRM at codons 12 and 13 was assessed using a primer extension assay SNaPshot ${ }^{\mathrm{TM}}$ (Applied Biosystems, Warrington UK). SNaPshot ${ }^{\mathrm{TM}}$ uses fluorescent dideoxynucleotides (ddNTPs) as the detection nucleotides. The region of interest of the KRAS gene is amplified by polymerase chain reaction (PCR) and the resultant product is purified by the removal of excess nucleotides and primers. For the primer extension step, detection primers and SNaPshot reaction mix, containing fluorescent ddNTPs, buffer and enzyme, which are then added to the purified PCR product. Each detection primer is extended by a single fluorescent nucleotide which, following alkaline phosphatase purification is detected by capillary electrophoresis. The results are analysed using fragment analysis software.

Statistical analysis was performed using the Fischer exact test for categorical outcomes and the Mann-Whitney $U$ test (MW-U) for continuous variables. A $p<.05$ (2-sided) was taken as the least of statistical significance.

\section{RESULTS}

Fourteen patients were recruited and consented for the study. Of these, 13 patients had undergone a pancreaticoduodenectomy and one patient had a distal pancreatectomy. The median age of the patients in the study was 68 (range 57-86) years. The $M: F$ ratio was 8 : 6. Of the 14 patients, 12 patients had adenocarcinomas ( 5 pancreatic; 4 ampullary, 3 biliary cancers) and 2 patients had benign mucinous tumours (BMT) (Table 1).

\section{TUMOUR KRM STATUS}

Six patients (6/12) with adenocarcinomas had KRM in their tumour tissue (5 in codon 12 and 1 in codon 13). The mutations and base substitutions are delineated in Table 1.

\section{NON-TUMOROUS MARGIN KRM STATUS}

Non-tumourous margin tissue was negative in all patients with cancer regardless of their tumour KRM status. ( $p=.014-$ Fisher).

III A) TUMOUR SIZE

Malignant tumours with KRM were significantly larger than wild type tumours, 30 (22-65) $\mathrm{mm}$ vs 20 (15-35) $\mathrm{mm}$ [median (range)] ( $p=.045-\mathrm{MW}-\mathrm{U})$.

III B) NODAL STATUS

Tumours with KRM were all node positive compared to wild type tumours $6 / 6$ vs $2 / 6$ ( $p=$ .06 - Fisher).

III C) VASCULAR INVASION

Vascular invasion was noted in 4/6 with KRM compared to 2/6 with wild type.

III D) PERINEURAL INVASION

Perineural invasion occurred in 5/6 in each group. 
British Journal of Medicine \& Medical Research, 3(4): 2069-2075, 2013

Table 1. Demographics, tumour characteristics, and KRM status in tumour and non-tumour margin

\begin{tabular}{|c|c|c|c|c|c|c|c|c|c|c|c|c|}
\hline No & Age & Gender & Operation & Tumour & Histology & $\begin{array}{l}\text { Differentia } \\
\text { tion }\end{array}$ & $\begin{array}{l}\text { Tumour } \\
\text { Size } \\
(\mathrm{mm})\end{array}$ & $\begin{array}{l}\text { Lymph } \\
\text { node } \\
\text { status }\end{array}$ & $\begin{array}{l}\text { Vascular } \\
\text { invasion }\end{array}$ & $\begin{array}{l}\text { Perineural } \\
\text { invasion }\end{array}$ & $\begin{array}{l}\text { K-Ras Mutation } \\
\text { Tumour KRM } \\
\text { (point base } \\
\text { substitution) }\end{array}$ & $\begin{array}{l}\text { Non-tumour } \\
\text { margin } \\
\text { KRM }\end{array}$ \\
\hline 1 & 70 & $\mathrm{M}$ & PD & Ampulla & Adenocarcinoma & Well & 12 & $0 / 9$ & $\mathrm{~N}$ & $\mathrm{~N}$ & No & No \\
\hline 2 & 73 & $M$ & PD & Ampulla & Adenocarcinoma & Mod-poor & 20 & $0 / 3$ & Y & $\mathrm{Y}$ & No & No \\
\hline 3 & 56 & $M$ & PD & Bile duct & Adenocarcinoma & Mod & 16 & $0 / 6$ & $\mathrm{~N}$ & Y & No & No \\
\hline 4 & 86 & $M$ & PD & Bile duct & Adenocarcinoma & Well & 20 & $0 / 19$ & $\mathrm{~N}$ & $Y$ & No & No \\
\hline 5 & 74 & $M$ & PD & Pancreas & Adenocarcinoma & Well & 35 & $6 / 27$ & $Y$ & Y & No & No \\
\hline 6 & 70 & $\mathrm{~F}$ & PD & Pancreas & Adenocarcinoma & Poor & 25 & $3 / 15$ & $\mathrm{~N}$ & $\mathrm{Y}$ & No & No \\
\hline 7 & 57 & $\mathrm{~F}$ & PD & Bile duct & Adenocarcinoma & Well & 22 & $1 / 11$ & $\mathrm{~N}$ & Y & $\begin{array}{l}\text { c. } 34 G>C \\
\text { (p.Gly12Arg) }\end{array}$ & No \\
\hline 8 & 67 & $\mathrm{~F}$ & PD & Ampulla & Adenocarcinoma & Mod-poor & 28 & $1 / 15$ & $\mathrm{~N}$ & $\mathrm{~N}$ & $\begin{array}{l}\text { c.38G>A } \\
\text { (p.Gly13Asp) }\end{array}$ & No \\
\hline 9 & 77 & $M$ & PD & Ampulla & Adenocarcinoma & Poor & 30 & $3 / 15$ & $Y$ & $\mathrm{Y}$ & $\begin{array}{l}\text { c. } 35 \mathrm{G}>\mathrm{A} \\
\text { (p.Gly12Asp) }\end{array}$ & No \\
\hline 10 & 64 & $\mathrm{~F}$ & PD & Pancreas & Adenocarcinoma & Well & 30 & $17 / 18$ & $Y$ & $\mathrm{Y}$ & $\begin{array}{l}\text { c.35G }>\text { T } \\
\text { (p.Gly12Val) }\end{array}$ & No \\
\hline 11 & 63 & $M$ & PD & Pancreas & Adenocarcinoma & Poor & 65 & $1 / 16$ & $Y$ & Y & $\begin{array}{l}\text { c. } 35 G>A \\
\text { (p.Gly12Asp) }\end{array}$ & No \\
\hline 12 & 69 & $\mathrm{~F}$ & PD & Pancreas & Adenocarcinoma & Well & 35 & $4 / 9$ & Y & $\mathrm{Y}$ & $\begin{array}{l}\text { c.34G>C } \\
\text { (p.Gly12Arg) }\end{array}$ & No \\
\hline 13 & 62 & $M$ & $\mathrm{DP}$ & Pancreas & $\begin{array}{l}\text { Benign mucinous } \\
\text { tumour }\end{array}$ & Well & 40 & $0 / 12$ & $\mathrm{~N}$ & $\mathrm{~N}$ & No & No \\
\hline 14 & 59 & $\mathrm{~F}$ & PD & Pancreas & $\begin{array}{l}\text { Benign mucinous } \\
\text { tumour }\end{array}$ & Well & 60 & $0 / 7$ & $\mathrm{~N}$ & $\mathrm{~N}$ & No & No \\
\hline
\end{tabular}

PD: Pancreaticoduodenectomy; DP: Distal pancreatectomy 


\section{DISCUSSION}

KRM was negative in non-tumorous margin tissue in all our patients, including patients who had KRM in tumour tissue. This sheds light on the mapping of molecular changes within pancreatic tumour tissue and the surrounding pancreatic parenchyma. The genomic mutations are therefore a local event within tumour tissue and not a widespread phenomenon.

In our series, tumours with KRM were larger and all had nodal disease. Fifty-percent of our patients had KRM in their tumour tissue. These results are comparable to another study that included periampullary tumours in addition to pancreatic cancers. Their overall incidence of KRM was 55\% [8]. Oliveira-Cunha et al reported that in a hundred patients in their series with pancreatic and periampullary cancers, the incidence of KRM was $41.2 \%$, and they went on to say that the true incidence of KRM may be far less common that previously reported [9]. They also found no correlation to survival.

It is interesting that although KRM is thought to occur in almost all pancreatic cancers, as an iniator to cancer progression or "sine quo non", studies have found prognostic significance of KRM in pancreatic cancer $[2,10]$. One study found that their incidence of KRM in their series of 272 pancreatic adenocarcinoma was $53.8 \%$, and KRM was associated with poor survival [10]. KRM in inoperable pancreatic cancer has been reported to be independent negative prognostic factor and is associated with reduced survival [11]. It may well be that these observations support that perhaps the incidence of KRM is lower than previously thought.

Our assessment of margin tissue involved peritumoural normal margin tissue. Given that genomic mutation is a local tumour event, then a margin with positive KRM may have clinical relevance. Kim et al found KRM in 53\% of their histologically negative margin tissue and found that this was associated with poor prognosis [12]. This is markedly different from our $0 \%$ in our margin assessment for important reasons. We evaluated histologically normal margin tissue for assessment of KRM, whereas Kim et al assessed histologically "negative" margin tissue. Their negative margin tissue was negative for cancer, but included premalignant lesions from low-grade to high-grade pancreatic intraepithelial neoplasia or PanIN, which account for this higher incidence of KRM and the discrepancy without findings.

Accurate assessment of KRM is imperative in an era of growing use of selective, targeted molecular and chemotherapeutic agents [13]. KRM status in lung and colorectal cancer, has led to advances in the management of these cancers, with personalised therapy based on KRM status [14,15]. This has included improved survival in patients with wild-type KRAS colorectal cancer undergoing anti-EGFR treatment [16]. The future holds promise for pancreatobiliary malignancies and potential treatment if we can extrapolate these advances to our practice.

\section{CONCLUSIONS}

KRM is a local event in pancreatobiliary tumours. KRM in our study was associated with larger malignant tumours and a trend towards nodal involvement. Accurate assessment of tumour KRM depends on study of tumour tissue as it is a local event. 


\section{CONSENT}

All authors declare that written informed consent was obtained from the patient (or other approved parties) for this study.

\section{ETHICAL APPROVAL}

The institutional ethics committee approved the study.

\section{ACKNOWLEDGEMENTS}

We would like to acknowledge our source of support for this study, the Pancreatic Cancer Research Grant, Royal Adelaide Hospital.

\section{COMPETING INTERESTS}

Authors have no competing interests to declare.

\section{REFERENCES}

1. Agbunag C, Bar-Sagi D. Oncogenic K-ras drives cell cycle progression and phenotypic conversion of primary pancreatic duct epithelial cells. Cancer Res. 2004;64(16):565963.

2. lacobuzio-Donahue CA. Genetic evolution of pancreatic cancer: lessons learnt from the pancreatic cancer genome sequencing project. Gut. 2012;61(7):1085-1094.

3. Longnecker DS, Terhune PG. What is the true rate of K-ras mutation in carcinoma $f$ the pancreas? Pancreas. 1998;17(4):323-324.

4. Lemoine NR, Jain S, Hughes CM, Staddon SL, Maillet B, Hall PA, et al. Ki-ras oncogene activation in preinvasive pancreatic cancer. Gastroenterology. 1992;102(1):230-236.

5. Friess $\mathrm{H}$, Kleef J, Korc M, Büchler MW. Molecular aspects of pancreatic cancer and future perspectives. Dig Surg. 1999;16(4):281-290.

6. Feldmann G, Beaty R, Hruban $\mathrm{RH}$, Maitra A. Molecular genetics of pancreatic intraepithelial neoplasia. J Hepatobiliary Pancreat Surg. 2007;14(3):224-232.

7. Delpu Y, Hanoun N, Lulka H, Sicard F, Selves J, Buscail L, et al. Genetic and epigenetic alterations in pancreatic carcinogenesis. Current Genomics. 2011;12(1):1524.

8. Schulz NA, Roslind A, Christensen IJ, Gaustadnes M, Johansen JS, Kruhøffner M, et al. Kras mutations and relation to prognosis in patients operated for localized pancreatic cancer and other periampullary cancers. J Clin Oncol. 2009;27 (ASCO 2009 abstract e 15618).

9. Oliveira-Cunha M, Hadfield KD, Siriwardena AK, Newman W. EGFR and KRAS mutational analysis and their correlation to survival in pancreatic and periampullar cancer. Pancreas. 2012;41:428-34.

10. Shin SH, Kim SC, Hong SM, Kim YH, Song KB, Park KM, Lee YJ. Genetic alterations of K-ras, p53, c-erbB-2, and DPC 4 in pancreatic ductal adenocarcinoma and their correlation with patient survival. Pancreas. 2013;42:216-22.

11. Chen $\mathrm{H}, \mathrm{Tu} \mathrm{H}$, Meng ZQ, Chen Z, Wang P, Liu LM. K-ras mutational status predicts poor prognosis in unresectable pancreatic cancer. Eur J Surg Oncol. 2010;36(7):657662. 
12. Kim J, Reber HA, Dry SM, Elashoff D, Chen SL, Umetani N, et al. Unfavourable prognosis associated with $\mathrm{K}$-ras gene mutation in pancreatic cancer surgical margins. Gut. 2006;55(11):1598-1605.

13. Shackelford RE, Whitling NA, McNab P, Japa S, Coppola D. Kras testing: A tool for the implementation of personalized medicine. Genes Cancer. 2012;3(7-8):459-66.

14. Bokemeyer C, Bondarenko I, Hartmann JT, de Braud F, Schuch G, Zubel A, et al. Efficacy according to biomarker status of cetuximab plus FOLFOX-4 as first line for metastatic colorectal cancer: the OPUS study. Ann Oncol. 2011;22(7):1535-46.

15. Dingemans AM, Mellema WW, Groen HJ, van Wijk A, Burgers SA, Kunst PW, et al. A Phase II Study of Sorafenib in Patients with Platinum-Pretreated, Advanced (Stage Illb or IV) Non-Small Cell Lung Cancer with a KRAS Mutation. Clin Cancer Res. 2013;19(3):743-51.

16. Bokemeyer C, Van Cutsem E, Rougier P, Ciardiello F, Heeger S, Schlichting M, et al. Addition of cetuximab to chemotherapy as first-line treatment for KRAS wild-type metastatic colorectal cancer:pooled analysis of the CRYSTAL and OPUS randomised clinical trials. Eur J Cancer. 2012;48:1466-75.

(C) 2013 Chandrasegaram et al.; This is an Open Access article distributed under the terms of the Creative Commons Attribution License (http://creativecommons.org/licenses/by/3.0), which permits unrestricted use, distribution, and reproduction in any medium, provided the original work is properly cited.

Peer-review history:

The peer review history for this paper can be accessed here: http://www.sciencedomain.org/review-history. php?iid=205\&id=12\&aid=1638 